\title{
The Effect of Recruitment, Selection and Development on Talent Management in IKCO Company in Iran
}

\author{
Bentolhoda Abdollahbeigi, Farhang Salehi and Sreenivasan Jayashree
}

\begin{abstract}
Background/Objectives: the talented people are important role of success in organizations, the goals of this study is to determine the used organization techniques to recruit and select, develop and maintain talent. Also examine the relationship between recruitment and selection, development used by organizations and their talent management. The survey method was selected for this research. Methods/ Statistical analysis: The Research tool is a structured questionnaire. This study is Settings of international companies in Iran. The Questionnaire was conducted by human resource managers in the organization. The result indicate that HR planning and selection are the most common techniques used by the organization to recruit and techniques. Also, training programs continuously developing talent is the method used by the organization to develop their talents. Findings: The findings showed that the most important strategy to preservation talent is clarifying job responsibilities and career paths. In this study is that what techniques are used for the recruitment and choosing in this organization to predict the talent management.
\end{abstract}

\section{Keywords}

Talent management, Appearance of talent management, Marketplaces for talent workforce, Challenge for talent management

\section{INTRODUCTION}

Talent person should be unique abilities, knowledge and skills. Talent segmentation plays important role in identifying talent with additional attention to develop the opportunity for bring new ideas that can better organization effectiveness and achieve to goals. The human resource management and line management has an influence talent management. "Talent management is an important mission process that assurance organizations have the quality and quantity of people in place to meet their current and future business precedence" Some managers believe that the investing in talent has high cost and prevented them of doing. One of the most important factors to successfully do the implementation of talent management is continual commitment from all organization levels and cannot be implemented and done by human resource.

Talent management can help the company to achieve economic and industrial development at national level. Also a firm with strong marketing competencies is able to use it deep understanding of customer needs to do faster development of new products and organize marketing activities which provide a unique value to customers. Also the ability to developing and design new products process and upgrade knowledge and transferring this knowledge into designs.

One of the important competitors for IKCO is Parskhodro Company. Parskhodro uses of talent management to find talent employees and train them and use their innovation and knowledge to add value to its products to gain competitive advantage in the market and it was successful to reach its goal.

\section{Problem statement}

Nowadays the recruitment, development and keeping of talent are very important in all company performance, and if organizations investment in talent management it's not cause to enough and satisfaction to achieve desired level of talent pool. Talent management must focus on all levels of an organization, and not only focus on top level. Talent management issue needs to be at business strategy of any organization.

Talent management includes recruitment; development of talent in the company and today's majority of companies doesn't focus on all component of talent management. Talent management is a new in Iran. Some organizations don't talent management to business strategy, so they fail to understand what success should look like for organizations. Find the talent management is so important for success of the companies. So they need to find how much talent management strategies are run in Iran IKCO. This is focus on this study.

\section{RESEARCH QUESTION}

(i). Is there a relationship between talent recruitment and selection techniques used by organization and Talent Management?

(ii). Is there a relationship between talent development techniques used by organizations and Talent Management?

\section{RESEARCH OBJECTIVES}

(i). To investigate the relationship between recruitment techniques used by organization and Talent Management? 
(ii). To investigate the relationship between talent development techniques used by organizations and Talent Management?

\section{SIGNIFICANCE OF STUDY}

Iranian company has a focus on managing and attracting people with high performance. When they select or recruit by organization, they should trained and maintain by organization and they can to reduce cost for organizations and staffs satisfaction that can help to organization profitability. What technique they used to help company for recruit and select the right people. Because the selection and recruitment are important for an organization and the organization must to recruit right people and train and develop them with technique for organization, so retain the right people is vital for organization. Investments the company for hiring, training and retaining them is so important.

\section{TALENT MANAGEMENT}

Talent management is a procedure appearance in 1990 and continues with adapted so many of companies come to understanding their talents of employees and drive of skills for success in their business. The talent management is a process by which organizations forecast human capital requirement and try to attract or keep the appropriate and eligible people in organizations. The talent has needs to continue for training and develop high performance for potential of the new roles, identifying the gaps of knowledge and perform plant for improve their competency or abilities and insure to maintain [1]. Three key of talent management activities performance among high performing organizations are: ensure of global stability in management process, to reach cultural diversity and expansion global leader [2]. Talent management so important that companies are forced to go where talent is and an organization performance looks that becomes more depends on employees skills. Talent management it seems to be central and significant duties, which HRM take part strategically in organizations [3]. Talent management is including all human resource process, administration and technologies. It usually refers to sourcing, selecting, retaining, development, establishment and renewable of workforce with analysis and planning. Also talent management is what occurs in relation of the recruit, development and process of management workforce and alternatively it can be describe as optimizing talent. There is no single compatible definition of talent management [4]. Programs of talent management is designed for establish pool of talent that can feed specific job category and individual skills development, competency and behaviours of those jobs and staffs that successful in the future. the more focus on development and investment widespread, talent mind set. As [5] Not different between talent management and human resource management both including take the right job in the right time and manage supply, demand and streaming of people via the organizations that it is including a set of human resource typically activities like: selection, hiring, training and evaluating, Shows that the majority of companies still intention to focus on top talent with nearly half the companies planning for maintains or increase learning and costs development. Mckinsey found three key of talent management activities performance among high performing organizations are: ensure of global stability in management process, to reach cultural diversity and expansion global leaders [2].

Talent management includes the accurate tools of strategic or process for increase the output of a workplace with the establishment improving processes and systems for absorption, developing, retain and use of required capabilities and skills workforce and matched the talent with present and future needs of bossiness. The meaning of talent management it is not exactly to define because each author has different definition and they have own definition and point of view toward talent management. The concept of talent management, strategy of talent, substitution management and HR planning are so close to each others that they can be replacement for each other. Talent management developed three main areas considered to be talent management. First is the talent management mix of roles, actions, such as: hiring, selection and developing the employees substitution planning and managing [6].

Talent management is about recognize recruitment, develop and retaining people with high performance and they can grow within the organization [7].Each organization has a different talent people and that can be changed and market changes. Some organization knows talent people in job performance, so the people with high job performance are more attention for these organizations [8]. Talent management in the marketplace is very important for organization to success. Some organization believes that effective talent management practices are important source in differentiation increase competitive integrated economy. Talent person should be unique abilities, knowledge and skills. Talent segmentation plays important role in identifying talent with additional attention to develop the opportunity for bring new ideas that can better organization effectiveness and achieve to goals. The human resource management and line management has an influence talent management. Talent management is an important mission process that assurance organizations have the quality and quantity of people in place to meet their current and future business precedence [25] .Some managers believe that the investing in talent has high cost and prevented them of doing. One of the most important factors for implementation successfully of talent management continual commitment from all organization levels and cannot be implemented and done by human resource.

\section{A. Recruitment and Selection Talent Management}

Recruitment and selection are a core human resource planning activities and are a vital part or section in organizations total strategic plan. Recruitment and section causes stability in an organization with attracting and hiring talented workers. Firstly, all organizations must recognize 
their needs and understand talent need in the market. If organizations understand different generation required and tendency, organizations can to find incentive and attitude. This can be a helpful for organizations to make up the strategies and technique that can support success recruitment and selecting process. Good recruitment and selecting is effect on improve organizations outcomes. [9] They show that the right strategies in recruitment and selection process can better the organizations efficiency. Recruitment Definition is a process for looking and absorption an eligible applicant's pool of that candidate can be selected the jab vacancies Selected [10].

\section{(i) HR Planning}

Some researchers have examined relationship between efficient management of human resource within the organization and customer reactions to service eligibility [11]. After expenditure time can help organizations to make a planned and tactical strategy to improve to talent competencies and make constancy and profitability for organizations. [12], [13] The defined for Talent management as comprehensive method used in planning with human resource sector to raise the abilities in organizations, improve or better performance, career developing, also centralization on planning within organizations. Now the talent management has development its role to general management centralization on hire to absorption the attention eligible people and also maintaining, satisfaction and incentive talent people [14] .So from the view of HR planning, talent management is a expending concept that covers policies to manage high value and high potential of staffs in organizational of different level these group of employees have specific skills and knowledge the job that they can make high value for organization. The concept of work life balance has changed nature of talent management that more based on the quality of work made with talented people than works quantity. And also the talent management is refer to having or gain the right people matched to the job right and time right and perform the right things [15]. they should sometimes identify with organization already has fast growth in experiencing that to the extent that is driving the talent system, and when they become more consistency in size of term of operations their perspective maybe change.

\section{(ii) Selection}

The selecting is a process that select or the choosing of a group of the best applicant's eligible candidate 16.Some organization use selection or choosing tools models facilitates selecting decisions. Management must running proven selecting of talent or chosen the systems and instruments for creating the right people that based on merit of high performance organization need to enhance diversity to retain people, reward to the high performance.

(iii) Action planning
The organizations can make up their talent management in this level in this level organizations take action plan that are precious and they are helpful for new system, like:

Pre Employment Actions: this action is helpful to identifying the goals in substitution planning; also, this is helpful to recognize the gap between current employees and external talent those can absorption by organizations.

In Employment Action: In hiring process the relationship between managers and talented candidate must be according to the employee value propositions.

Exit Related Action: In this levels the organizations preservation their contact with their employee that leaves the organizations for 6 months. Also it can development the network to absorption and return eligible labor outside the organizations.

\section{B. Development of Talent}

Development of talent is a part of HR development and this trend can exist in change in an organization. Also its employees can use planned and unplanned learning for reach and retention a competitive advantage for organizations. Developing talent is so important in an organizations for maintain business growth. Companies need to understand which this is better to indicate their employees that they are committed and care about them. Also the developing talent can help to increase employee's ability that cause increasing their competitive advantage against their competitors. They goals are staffs development skills to help to achieve their business goals and help them to achieve their full potential.

\section{(i) Mentoring}

The mentoring is a one of procedure of talent development which managers create the incentive talent for support the employees for reach their ideal expectations. The mentor must help to improve these problems and help talent to reach the desirable level of performance and also support talent to have more satisfaction and commitment about job and organizations. Working for maintain strong talent in the organizations. Mentors develop and keep talent with helping new employees learn about the organizations .mentors help employees that attention how they would like to grow as a professional company programs to registers, new skills to develop and career growth to look. Mentoring relationship can help keep talented people because they have a stronger commitment to the organizations. Also the monitoring enables any of employees to achieve their full potential in the organizations.

\section{(ii) Training}

Employees training and development is not mean just to earn new knowledge, ability and skills but also enable to promote entrepreneurship, introduce employee for changes, encourage the changes of their attitude, introduce employee to important business for decisions and including activities them in the process of decision making. The employees quality and developing their by train and educate are major causes in 
determine the long-term profitability from a small business. If they hiring and keeping good employees, this is good policy for investing in developing their skills, so they can increase their productivity or efficiency.

\section{(iii) Succession Planning}

Succession planning is necessary factors that can helps to organizations to knows their target and choose the right people. Also succession planning is defined as a dynamic process of systematically and developing the leadership talent and developing and identifying key employees to meet future organization strategy and operational needs. One of the most important issues facing every global business is that of developing and keeps a succession plan to meet the organizations future management needs. The succession planning is:

Leadership building is the talent pool for assurance continuity the leadership. The potential for developing substitutes methods which better to proportional their strengths. Recognize the best candidate for group of position. The planning of Succession creates an efficient process to identify, develop and retain top leadership of talent.

\section{(iv)Career Management}

Managing of Talent understanding is from static succession to action oriented activity by different level of stress on substitution planning [17]. Any employees have an opportunity to have an individual plan and organizations create position actually and clearly for the future.[18] Succession plan allows organizations to plan for who will do key roles in the future and avoid the cost $\mathrm{s}$ with succession a key employee. supporting the use of career management service, such as projects a positive view of the organization, and supporting employees to assess career management helps driven skills and abilities of individual to ensure greater productivity individual can benefit from obtain a stronger understanding of their career capital (value, skills, abilities) and focusing on their personal objective to develop personal development plans. High rank situation like managerial and specialist are not easy to be filled. If organizations know their talent pool and use them to fill situations they can decrease the time and cost of talent recognition.

Organizations can decrease their cost by identifying of internal talent and use them to fill position. Also talent management provides a relationship between important operational needs with HR management [19]. Also, assessment methods give chance to correction the evaluation of their strong points in defining and maintain internal talent. Also if the organizations identifying with their talent potentials so, they can response the problems in employees, diversification, employees, and maintain the talent potential for organizations target and protect of organizations profitability [20].

Utility and importance of general knowledge can transferred and improve during the time and this knowledge can be correction to meet organizational needs and can help to people talent for uncertainly in new markets and very competitive. One of the main factors that essential to reach a well organized career management is training and development. More organizations hold talent, more the likelihood which competitors attacking the pool of talent.

\section{APPEARANCE OF TAlent MANAGEMENT}

Some of the organizations centralization on foreign labor but the talent management point of view is according to the development and improvement of internal labor KSAOs: knowledge, skills, abilities) among the caching for top level human capital, development to provide assignment and investment on substitution planning. In 1990 the organizations encountered pool of insert eligible talent and employers look to absorption talent with external recruitment. So the quality of talent is so important, the organization realized which when they lost their internal employee experienced they requirement to alternatives with absorption external labour. So retain eligible individuals and absorption retaining outside employees are the most important worry by organizations. Often organization must investment on internal development because the positive effect of internal development on success of organizations.

\section{MARKETPLACES FOR TALENT WORKFORCE}

Many organizations waste their time and money for $\mathrm{m}$ make competitive value on talented people with high ability within the organizations. While some organizations do not taking their internal talent pool as a source of competitive advantage and also is not considerable their strategy on talent management. Few of companies are centralization on labor of talented for the best use of incentive and innovation to gain their job knowledge and skill to improve their organizational skills. In the organizations the intangible asset including job knowledge, particular skills, client relationship make the important and add value for organizations. Also distribution of resource valuable is required for develop the talent needed for take chance. The managers have better chance to absorption and organize the talent that can help to reach their goals in the organizations if be a trend for internal talent market development. For employers is hard to identifying the staff with the highest possibility to be the best for existing jobs. Many companies usually devote by personal connection between individuals heads and individual employees or within small group. For manager is hard to understand who will be the best person for available position in firm's talented workers. Also this is hard for talented people that what opportunities exist in the company. Often, mostly the organizations expend their trying on level and excellence in its line of talent management and comparison with other group of expert labour. The companies allocated their money and time for better general managers and help them to improve their hierarchy situation than expenditure it for the talent required 
for individual client's relationship development, suppliers [21]. Also talented labours are incentive by rewards of the line management and effort to find the chance in line than professional management.

\section{The Problems And Challenge for Talent MANAGEMENT}

In talent management process organization need to see the future for determine the distance between human capital needs and availability. Talent management centralization in high level of managerial and executive in the organization, the most important things here is according to absorption the right people with the right skill to the right job for meet both person, job and person, organizations match in all jobs which perhaps is not easy to find the right people. Ability and skills of organizations depend on the decision making of talent management and determination who works for the organizations. Also they can provide economic consistency to the community. Failure in manage talent as surplus workforce that causing to reconstruction or workforce deficient in talent pipeline. Organizations Demand and supply are not in equilibrium and there is a high rate of high level of people. Also, human resource with a real challenge for both recruits and maintains people with varied skills. As a result, need of organizations not able to be satisfied as a result of lack in talented labours.

\section{RESEARCH FRAMEWORK}

For avoid of present challenges this is essential for companies to change their recruiting, training and rewarding systems according to the tasks which form their business plan. To respond the challenge, the organizations should review hat how they recruiting, training and reward their staffs, With put those tasks at their business plan, also in this position they can analyze the problems and find the best solution than only waste their valuable researches. Planning and hiring employees, performance evaluation, learning, career development, substitution planning, compensation, assessment and reporting of result that combined elements of talent management framework. Also this system is able to help the organizations to leverage output of talent management like, satisfaction of employees, commitment, incentive, performance and efficiency (Fig. 1).

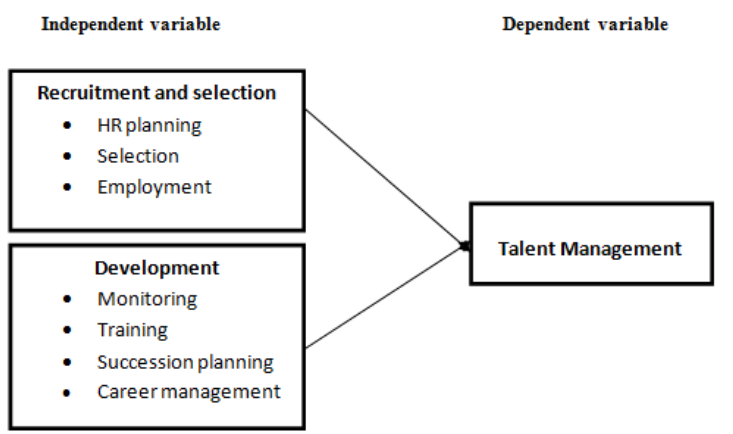

Fig.1. Research framework for the determinants of talent management.

\section{RESEARCH HYPOTHESIS}

\section{A. Hypothesis 1}

There is a positive relationship between recruitment techniques used by the organizations and management of their talent.

\section{B. Hypothesis 2}

There is a positive relationship between the talent development techniques used by organizations and manage their talent

\section{RESEARCH METHODOLOGY}

In this investigation will be used of qualitative research design. The definition of the qualitative method is research which including analyzing and interoperation of text and interviews for discover significant patterns descriptive of specific phenomenon. In this survey method will be used data collection. The populations are the IKCO Company. Convenience sampling will used in this research just as companies that agreed for participate in this study will be choosing. Sampling for this study is 36 sections in IKCO which they ate working separately as an organization and also they are dependent in output. In this survey, questioner by self run and personally distributed by the researcher to the subject to the subject.

The questionnaire includes five parts. For analysis of questions, a computer program (SPSS) will be used.. For answer the research question and test hypothesis are used both descriptive and inferential statistics were used. Descriptive statistics were used to describe the organizational specification which participated in this study.

For analysis of questions, a computer program (SPSS) was used. In this research used of data analyzed with "SPSS version 17" software. For answer the research question and test hypothesis are used both descriptive and inferential statistics were used. Descriptive statistics were used to describe the organizational specification which participated in this study, also hiring of talent, developing and strategies of management used in organization.

\section{DATA ANALYSIS}

\section{A. Sections in IKCO}

Out of 36 IKCO sections, 25 show which, used talent management in their sections. In below, there is the detail of 36 sections that participate in this survey from the stand point percentage. Also according to table 1 the 25 percent of respondents working for manufacturing section, 8.3 percent working in information section, 16.7 percent working in marketing services, and 2.8 percent is in public services, 11.1 percent working in transportation section and, 2.8 percent working in financial service, 33.3 percent working in technology section. The maximum of respondent is belongs to technology section (33.3 percent) and the minimum of respondent is belong to public services (2.8 percent) (Table 1).

Bentolhoda Abdollahbeigi, Farhang Salehi and Sreenivasan Jayashree,“ The Effect of Recruitment, Selection and Development on Talent Management in IKCO Company in Iran,” International Journal of Advanced Engineering and Management, vol. 2, no. 3, pp.69-77, 2017. 
Table 1. Distribution of Sections in IKCO

\begin{tabular}{|l|c|c|}
\hline Section & Frequency & Percentage \\
\hline Manufacturing & 9 & 25 \\
\hline Information & 3 & 8.3 \\
\hline Marketing Services & 6 & 16.7 \\
\hline Public Service & 1 & 2.8 \\
\hline Transportation & 4 & 11.1 \\
\hline Financial & 1 & 2.8 \\
\hline Technology & 12 & 33.3 \\
\hline Total & 36 & 100 \\
\hline
\end{tabular}

\section{B. Number of Employees and Age of Each Section}

The minimum numbers of employees in each section are 15 and the maximum numbers of employees in the each section are 3100 . So the outcomes indicate that this section is not newly established. Also the oldest establishment is 50 years and the newest is for four years (Table 2).

Table 2. Distribution of the Respondents According to Number of Employees and Age of Each Section

\begin{tabular}{|c|c|c|c|c|c|}
\hline & N & Min & Max & Mean & $\begin{array}{c}\text { Std } \\
\text { Deviation }\end{array}$ \\
\hline $\begin{array}{c}\text { Number of } \\
\text { Employee }\end{array}$ & 36 & 15 & 3100 & 339.86 & 790.799 \\
\hline $\begin{array}{c}\text { Establishment of } \\
\text { Section (Year) }\end{array}$ & 36 & 4 & 50 & 27.38 & 14.497 \\
\hline
\end{tabular}

\section{Hiring and Selecting Strategies of Talent}

The range of this scale from strongly disagree is shown in number one to strongly agree in number five is shown. The average score is three. It means which each section is taking initiative to recruit talent.

Also the maximum means is for align employees with mission and vision of each section with 4.19 and the minimum is the employment terms and conditions facilitates talent recruitment with value of 3.50. also 91.7 percent of each section said which the recruitment initiative are balance to the mission and vision of each section that lower than half of the each section $(47.3 \%)$ reported which the recruitment condition and terms presented by the each section facilitate in recruitment of talent.

More than two third of each section create a culture which makes people want to join the each section (72.3\%) and using choose strategies used by each section can each section to obtain talent(69.4\%) through the strategies for talent recruitment. Only more than half of each section (55.5\%) have agreed. the selection strategy used by each section can them to obtain the talent is there (Table 3 ), (Table 4 ).

\section{Talent Development Strategies}

Mean more than 3.5 scores shows that the each section use the strategies to average extent for developing talent. Also 3 strategies which is presenting training opportunities for skill up gradation is (4.03), presenting job challenge is (4.0) and creating policies that career growth is (3.94).
Table 3. Distribution of Talent Recruiting and Selecting Strategies \begin{tabular}{|l|l|l|l|l|l|l|}
\hline Recruitment & Strongly & Agree & Neutral & Disagree & Strongly & Mean
\end{tabular}

\begin{tabular}{|l|l|l|l|l|l|l|}
$\begin{array}{l}\text { and Selection } \\
\text { Strategies }\end{array}$ & $\begin{array}{l}\text { Agree } \\
(\%)\end{array}$ & $(\%)$ & $(\%)$ & $(\%)$ & $\begin{array}{l}\text { Disagree } \\
(\%)\end{array}$ & \\
\hline $\begin{array}{l}\text { Recruitment } \\
\text { initiatives } \\
\text { align } \\
\text { employee } \\
\text { with the } \\
\text { mission and } \\
\text { vision of } \\
\text { each section }\end{array}$ & 30.6 & 61.1 & 5.6 & 2.8 & - & 4.19 \\
\hline $\begin{array}{l}\text { Candidates } \\
\text { skills are } \\
\text { assessed } \\
\text { earlier in the } \\
\text { hiring } \\
\text { process }\end{array}$ & 11.1 & 58.3 & 25 & 5.6 & - & 3.75 \\
\hline $\begin{array}{l}\text { Creating } \\
\text { culture that } \\
\text { makes } \\
\text { individuals } \\
\text { want to join } \\
\text { the each } \\
\text { section }\end{array}$ & 16.7 & 55.6 & 27.8 & - & - & 3.89 \\
\hline
\end{tabular}

Table 4. Distribution of Talent Recruiting and Selecting Strategies

\begin{tabular}{|l|l|l|l|l|l|l|}
\hline $\begin{array}{l}\text { The planning by the HR } \\
\text { department identifies the } \\
\text { talent required by each } \\
\text { section }\end{array}$ & 13.9 & 41.7 & 36.1 & 8.3 & - & 3.61 \\
\hline $\begin{array}{l}\text { The selection strategies } \\
\text { enables my organization } \\
\text { to acquire talent }\end{array}$ & 8.3 & 47.2 & 41.7 & 2.8 & - & 3.61 \\
\hline $\begin{array}{l}\text { The employment terms } \\
\text { and conditions facilities } \\
\text { talent recruitment }\end{array}$ & 5.6 & 41.7 & 50 & 2.8 & - & 3.5 \\
\hline
\end{tabular}

Mean the scores near 4 or more than 4 shows which these strategies can be used much more. $3 / 4$ of each section announced which each section make policies which encourage career growth (77.8) ,provide job challenge (75\%) and providing training opportunities for skill up gradation(75\%) . the lowest score is for succession planning is through talent development (3.56). just $42.7 \%$ of each section used this strategy (Table 5).

\section{E. Talent Management Strategies}

Just 2 strategies get an average score more than three. A little more than two third of each section (64\%) reported that each section have particular talent management initiative in place. It also reported (64\%) which talent management initiatives were top preference in each section. Less than a third of each section (30.6\%) said that they had employee member that situation is only responsible for monitoring talent management initiatives (Table 6).

\section{F. Reliability Statistic for the Questionnaire on Talent Management}

The Pearson moment solidarity used to realize relationship between independent variables, recruiting and selecting, 
development with the dependent variable of talent management (Table 7).

Table 5. Distribution of Talent Development Strategies

\begin{tabular}{|c|c|c|c|c|c|c|}
\hline $\begin{array}{c}\text { Talent } \\
\text { Developme } \\
\text { nt } \\
\text { Strategies }\end{array}$ & $\begin{array}{l}\text { Strongl } \\
y \\
\text { Agree } \\
(\%)\end{array}$ & $\begin{array}{l}\text { Agre } \\
\text { e } \\
(\%)\end{array}$ & $\begin{array}{l}\text { Neutr } \\
\text { al } \\
(\%)\end{array}$ & $\begin{array}{c}\text { Disagre } \\
\mathrm{e} \\
(\%)\end{array}$ & $\begin{array}{c}\text { Strongl } \\
y \\
\text { Disagre } \\
\text { e (\%) }\end{array}$ & $\begin{array}{c}\text { Mea } \\
\mathrm{n}\end{array}$ \\
\hline $\begin{array}{c}\text { Creating } \\
\text { policies } \\
\text { that } \\
\text { encourage } \\
\text { s career } \\
\text { growth }\end{array}$ & 22.2 & 55.6 & 16.7 & 5.6 & - & 3.94 \\
\hline $\begin{array}{c}\text { Identifying } \\
\text { gaps in } \\
\text { current } \\
\text { employees } \\
\text { and } \\
\text { candidates } \\
\text { competenc } \\
\text { y levels }\end{array}$ & 22.2 & 41.7 & 33.3 & - & 2.8 & 3.81 \\
\hline $\begin{array}{c}\text { Providing } \\
\text { job } \\
\text { challenge }\end{array}$ & 25 & 50 & 25 & - & - & 4 \\
\hline $\begin{array}{l}\text { Providing } \\
\text { training } \\
\text { opportuniti } \\
\text { es for skill } \\
\text { up } \\
\text { gradation }\end{array}$ & 30.6 & 44.4 & 22.2 & 2.8 & - & 4.03 \\
\hline $\begin{array}{c}\text { Promotions } \\
\text { are based } \\
\text { on talent }\end{array}$ & 8.3 & 61.1 & 27.8 & 2.8 & - & 3.75 \\
\hline $\begin{array}{c}\text { Training } \\
\text { programs } \\
\text { are } \\
\text { constantly } \\
\text { carried out } \\
\text { to develop } \\
\text { talent }\end{array}$ & 8.3 & 66.7 & 22.2 & 2.8 & - & 3.81 \\
\hline $\begin{array}{c}\text { Succession } \\
\text { planning is } \\
\text { through } \\
\text { talent } \\
\text { developme } \\
\text { nt }\end{array}$ & 11.1 & 36.1 & 50 & 2.8 & - & 3.56 \\
\hline
\end{tabular}

Table 6. Distribution of Talent Management Strategies

\begin{tabular}{|c|c|c|c|c|c|c|}
\hline $\begin{array}{c}\text { Talent } \\
\text { Manageme }\end{array}$ & $\begin{array}{c}\text { Strongl } \\
\mathrm{y}\end{array}$ & $\begin{array}{c}\text { Agre } \\
\mathrm{e}\end{array}$ & $\begin{array}{c}\text { Neutr } \\
\text { al }\end{array}$ & $\begin{array}{c}\text { Disagre } \\
\mathrm{e}\end{array}$ & $\begin{array}{c}\text { Strongl } \\
\mathrm{y}\end{array}$ & $\begin{array}{c}\text { Mea } \\
\mathrm{n}\end{array}$ \\
Atrategies & $(\%)$ & $(\%)$ & $(\%)$ & $\begin{array}{c}\text { Disagre } \\
\mathrm{e}(\%)\end{array}$ & \\
\hline
\end{tabular}

\begin{tabular}{|c|c|c|c|c|c|c|}
\hline $\begin{array}{l}\text { Having a } \\
\text { staff } \\
\text { member } \\
\text { whose } \\
\text { position is } \\
\text { for } \\
\text { overseeing } \\
\text { talent } \\
\text { manageme } \\
\text { nt initiative }\end{array}$ & - & 30.6 & - & 69.4 & - & 2.61 \\
\hline $\begin{array}{c}\text { Section } \\
\text { has a } \\
\text { specific } \\
\text { talent } \\
\text { manageme } \\
\text { nt initiative } \\
\text { in place }\end{array}$ & - & 69.4 & - & 30.6 & - & 3.39 \\
\hline $\begin{array}{c}\text { Talent } \\
\text { manageme } \\
\mathrm{nt} \text { initiative } \\
\text { is a top } \\
\text { priority in } \\
\text { each } \\
\text { section }\end{array}$ & - & 63.9 & - & 36.1 & - & 3.28 \\
\hline \multicolumn{7}{|c|}{$\begin{array}{c}\text { Reliability Statistics for the Questionnaire on Talent } \\
\text { Management }\end{array}$} \\
\hline No & \multicolumn{3}{|c|}{ Constructs } & \multicolumn{3}{|c|}{$\begin{array}{l}\text { Cronbach Alpha } \\
\text { Values }\end{array}$} \\
\hline 1 & & \multicolumn{2}{|c|}{ Management } & & 0.7 & \\
\hline 2 & \multicolumn{3}{|c|}{ Recruitment } & \multicolumn{3}{|c|}{0.82} \\
\hline 3 & \multicolumn{3}{|c|}{ Development } & \multicolumn{3}{|c|}{0.86} \\
\hline
\end{tabular}

Since the Coronbach alpha values are above

0.7 , the questionnaire is deemed to be reliable for use in this research.

Table 7. Reliability Statistic for the Questionnaire on Talent Management

\begin{tabular}{|c|c|c|}
\hline $\begin{array}{c}\text { Factor Influencing Talent } \\
\text { Management }\end{array}$ & $r$ & $\mathrm{P}$ \\
\hline Recruitment and Selection & 0.388 & 0.019 \\
\hline Development & 0.275 & 0.104 \\
\hline
\end{tabular}

G. Product Moment Correlation Analysis of the Factors

\section{Influencing Talent Management}

The outcomes shows that just recruitment and selection ( $\mathrm{r}$ $=0.388, \mathrm{p}<0.05$ ) had significant relationship with talent management. Also the relationship between development and talent management was not significant $(\mathrm{r}=0.275, \mathrm{p}>0.05)$. [22] That indicated many of each section are unsuccessful

Bentolhoda Abdollahbeigi, Farhang Salehi and Sreenivasan Jayashree,“ The Effect of Recruitment, Selection and Development on Talent Management in IKCO Company in Iran," International Journal of Advanced Engineering and Management, vol. 2, no. 3, pp.69-77, 2017. 
developing and keep their qualified workforce. In each sections development are not sufficient to supporting the talent management. According on above outcomes, just one of three hypothesis of research is not rejected. Hypothesis 1 that suggested which is a positive relationship between technique of recruitment and talent management is not rejected. Hypothesis 2 that suggested which is a positive relationship between technique of development and talent management (Table 8) and Table 9 This table show there is correlation between independent variables and dependent variable.

Table 8. Pearson Product Moment Correlation Analysis of the factors Influencing Talent Management

\begin{tabular}{|c|c|c|c|c|}
\hline & $\begin{array}{c}\text { Talent } \\
\text { Manageme } \\
\text { nt }\end{array}$ & $\begin{array}{c}\text { Recruit } \\
\text { ment }\end{array}$ & $\begin{array}{c}\text { Develop } \\
\text { ment }\end{array}$ & $\begin{array}{c}\text { Retentio } \\
\mathrm{n}\end{array}$ \\
\hline $\begin{array}{c}\text { Talent } \\
\text { Management } \\
\text { Pearson } \\
\text { Correlation } \\
\text { Sig.(2-tailed) } \\
\text { N } \\
\end{array}$ & $\begin{array}{c}1 \\
36\end{array}$ & $\begin{array}{c}0.388^{*} \\
0.019 \\
36\end{array}$ & $\begin{array}{c}0.275 \\
0.104 \\
36\end{array}$ & $\begin{array}{c}0.191 \\
0.263 \\
36\end{array}$ \\
\hline $\begin{array}{l}\text { Recruitment } \\
\text { Pearson } \\
\text { Correlation } \\
\text { Sig.(2-tailed) } \\
\text { N }\end{array}$ & $\begin{array}{c}.388^{*} \\
0.019 \\
36\end{array}$ & 36 & $\begin{array}{c}0.807 * * \\
0 \\
36\end{array}$ & $\begin{array}{c}0.655^{* *} \\
0 \\
36\end{array}$ \\
\hline $\begin{array}{l}\text { Development } \\
\text { Pearson } \\
\text { Correlation } \\
\text { Sig.(2-tailed) } \\
\text { N }\end{array}$ & $\begin{array}{l}0.275 \\
0.104\end{array}$ & $\begin{array}{c}0.807^{* *} \\
0\end{array}$ & 36 & $\begin{array}{c}0.848^{* *} \\
0\end{array}$ \\
\hline
\end{tabular}

Table 9.Correlation between Recruitment and Selection, Development with Talent Management for Model 1

\begin{tabular}{|c|c|c|c|c|c|c|c|c|}
\hline \multicolumn{4}{|c|}{ Parameters } & \multicolumn{5}{|c|}{ Change Statistics } \\
\hline$\simeq$ & 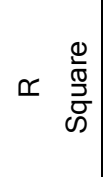 & 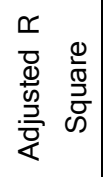 & 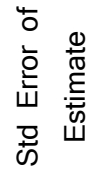 & 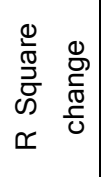 & \llcorner & $\frac{5}{5}$ & 政 & 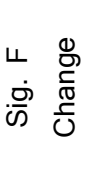 \\
\hline $\begin{array}{c}\infty \\
\infty \\
m \\
0\end{array}$ & $\frac{5}{0}$ & $\stackrel{\stackrel{0}{N}}{\stackrel{0}{0}}$ & 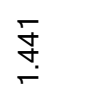 & $\stackrel{\overline{5}}{\overline{0}}$ & \begin{tabular}{l}
\multirow{0}{0}{} \\
0
\end{tabular} & - & 声 & $\begin{array}{l}\frac{\Omega}{0} \\
0 \\
0\end{array}$ \\
\hline
\end{tabular}

\section{H. Forecast of Talent Management}

Simple regression analysis used for finding the contribution of three independent variables of recruitment and selection techniques to talent management. The outcomes are providing in table 9 multiple regression analysis of forecast of talent management using the stepwise method: The table 10 multiple regression analysis of forecasting of talent management using the stepwise method.

This outcome indicates that just recruitment and selection techniques are considerable forecasting of talent management $(\mathrm{F} 1,34=6.040, \mathrm{p}<0.05)$. It explains $15.1 \%$ of talent management in each section which examined.

\section{Regression}

First hypothesis says that there is a positive relationship between recruitment techniques used by organizations and Bentolhoda Abdollahbeigi, Farhang Salehi and Sreenivasan Jayashree,“ The Effect of Recruitment, Selection and Development on Talent Management in IKCO Company in Iran," International Journal of Advanced Engineering and Management, vol. 2, no. 3, pp.69-77, 2017.
Talent management in IKCO Company in Iran. According to Table 9.A, we can see that there is positive relation, and $\mathrm{H} 1$ is accepted. Second hypothesis says that there is a positive relationship between talent development techniques used by organizations and Talent management in IKCO Company in Iran, According to Table 9. B we can see that there is weak positive relation, and $\mathrm{H} 2$ is accepted.

Table 9. Multiple Regression Analysis of Forecast of Talent

Table 9 A. Model Summary

\begin{tabular}{|c|c|c|c|c|c|c|c|c|c|}
\hline \multicolumn{5}{|c|}{ Parameters } & \multicolumn{5}{|c|}{ Change Statistics } \\
\hline $\begin{array}{l}\overline{\overline{0}} \\
\frac{0}{\Sigma}\end{array}$ & $\simeq$ & $\begin{array}{l}\frac{0}{\frac{1}{0}} \\
\frac{0}{0} \\
\mathscr{\omega} \\
\simeq\end{array}$ & 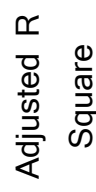 & 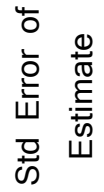 & 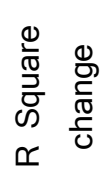 & ч & $\frac{E}{0}$ & $\frac{N}{0}$ & 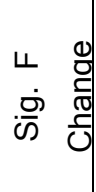 \\
\hline- & $\begin{array}{l}\infty \\
\infty \\
\text { ల్ } \\
0\end{array}$ & $\frac{5}{5}$ & $\frac{\stackrel{0}{N}}{\stackrel{0}{0}}$ & $\underset{\leftarrow}{\stackrel{f}{f}}$ & $\frac{\overline{5}}{5}$ & $\begin{array}{l}\tilde{O} \\
\dot{0}\end{array}$ & 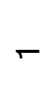 & ले & $\frac{0}{0}$ \\
\hline
\end{tabular}

Table 9 B. Model Summary

\begin{tabular}{|c|c|c|c|c|c|c|c|c|c|}
\hline \multicolumn{5}{|c|}{ Parameters } & \multicolumn{5}{|c|}{ Change Statistics } \\
\hline $\begin{array}{l}\frac{\bar{\sigma}}{\delta} \\
\frac{0}{2}\end{array}$ & $\simeq$ & 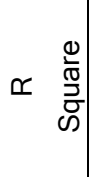 & 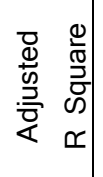 & 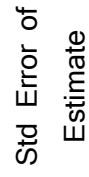 & 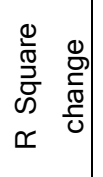 & ᄂ & $\frac{5}{0}$ & $\frac{0}{0}$ & 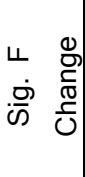 \\
\hline- & 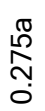 & $\begin{array}{l}\stackrel{0}{0} \\
0 \\
0 \\
0\end{array}$ & $\begin{array}{l}\frac{10}{0} \\
0 \\
0\end{array}$ & & $\begin{array}{l}0 \\
0 \\
0 \\
0\end{array}$ & مُ & - & লे & 足 \\
\hline
\end{tabular}

A. Predictors: (Constant), recruitment B. Dependent Variable: Talent Management

\section{CONCLUSION}

In IKCO international company, coordinate staffs with the mission and vision of the organization technique, that necessary to further improvement in hiring and selection of talent. It look which the organization evaluate the candidates skills before in the recruiting process, however these skill must be associated with the organization's mission and vision. This concept is which selecting the right people that have the right knowledge, skills, ability and attitude with the mission and vision of the organization is the centralization on recruiting and selecting techniques in this organization. The recruiting and selecting technique of successful organization in the hr planning section can to recognize the talent needs by this organization and also selecting strategies used by them that can organization to obtain talent. Any way this organization is less successful with the recruiting rules and condition which facilitate talent management. In talent development, the IKCO Company required to improve the training methods and present opportunity for promote of talent skills. Which talent investment and organizational development provides in long term needed [23]. Distribution of organization success in talent development, indicate which 
it successful in providing training program continuous developing talent of their staffs. Also they are less successful in substitute planning for developing talent. When staffs leave the organization, the important worry in this organization is drop in service quality, when the organization was not worried about loss of business opportunities. In the other hand which the important focus of keeping initiatives in the organization is leverage available talent the present potential than absorption and hiring new talent which are exist in the market. Also the organization must improve current culture and change to the culture that cause the staffs want to stay in this organization. In this study, staffs have an opportunity that have an individual career plan and organizations must make regulations of future form position for the staffs. These organizations are successful in pension strategies to keeping the talents; also they are not successful in their general compensation systems to talent reward.

\section{XV.SUMMARY OF THE FINDING}

Today, the basic and main worries of managers are incentive competition and lack of highly aware staffs in this survey ,examined two fields, 1- identify the recruiting and selecting, development, and talent management technique that used by IKCO in Iran to selecting, develop and recruit talent. 2- The relationship between, recruit, development technique that used by organization and their talent management was examined.3- This study specified that of three techniques of recruitment and selection development is the best predictor of successful talent management in international company which was centralization of this study. The technique for talent management shows, which many of the organizations had particular talent management initiative in place, the concept is that each section of IKCO has specific technique and ways for talent management. The talent management is in the role of mindset and every organization has a specific method for managing talent but the talent management initiatives are not high precedence in this organization. This researcher indicates which though the recruitment and selection and development techniques related with talent management, just recruitment and selection is a considerable predictor of talent management. [24]. that indicate the talent identification, training them can directly affect on managing talent. In this research shows that obtained with the regression outcome, just $15.8 \%$ of talent management able explained with organizations recruiting, development and selection. $15.1 \%$ of talent management is explained about recruiting and selection techniques. The concept is in these organizations the recruitment and selecting method is the main method used for managing talent.

\section{REFERENCES}

1. A. Ariss, W. F. Cascio and J. Paauwe. Talent Management: Current Theories and Future Research Directions. Journal of World Business, vol.49, pp. 173-179, 2014.

2. Collings, D. G., Scullion, H., \& Vaiman, V.. Talent Management: Progress and Prospects. Human Resource Management Review, vol. 25, pp. 233-235,2015.
3. A. Dhotre. Attrition in Pharmaceutical Industry: Human Resource Management's Role and Strategy. International Research Journal, vol.1, no.11, pp. 87-89,2010.

4. V. Ramar et al. Talent Management Pattern for HR Professionals. Journal of Applied Engineering Research. II: Member I pp. 564-572, 2016.

5. E. Blass, A. Knights and A. Orbea. Developing Future Leaders: The Contribution of Talent Management. Ashridge Business School Presented at Fifth International Annual Conference on Leadership. vol. (iss), pp.181-199, 2008.

6. M.C. Meyers, M. van Woerkom, and N. Dries, Talent Innate or Acquired? Theoretical Considerations and Their Implications for Talent Management. Human Resource Management Review, vol. 23, pp.305-321, 2013.

7. M.C. Meyers and M. van Woerkom. The Influence of Underlying Philosophies on Talent Management: Theory. Implications for Practice, and Research Agenda. Journal of World Business, vol. 49, pp. 192-203, 2014.

8. L, Samuel. From Talent Compliance to Talent Commitment. Strategic HR Review. vol. 6, no. 3, pp.32-35, 2009.

9. M. Armstrong and S. Taylor. Armstrong's Handbook of Human Resource Management Practice. London: Kogan Page Publishers, 2014.

10. A. A. Katou. Investigating Reverse Causality between Human Resource Management Policies and Organizational Performance in Small Firms. Management Research Review, vol.35, no.2, pp. 134-156, 2012. http://dx.doi.org/10.1108/01409171211195161.

11. S. Upamanyu. Managing Attrition through HR System in Hotel Industry. International Journal of Multidisciplinary Approach \& Studies, vol.1, no. 6, pp.510-522, 2014.

12. D. G. Collings and k. Mellahi. Talent management: A Review and Research Agenda. Human Resource Management Review, vol.19, pp. 304-313, 2009.

13. S. Mastracci. Evaluating HR Management Strategies for Recruiting and Retaining IT Professionals in the U.S. Federal Government. Public Personnel Management, vol.38, no. 2, pp. 19-34, 2009. http://dx.doi.org/10.1177/009102600903800202.

14. V. Vaiman, H. Scullion and D. Collings. Talent Management Decision Making. Management Decision, $\begin{array}{llll}\text { vol.50 no.5, pp. } & \text { 925-941. } & 2012\end{array}$ http://dx.doi.org/10.1108/00251741211227663.

15. W. J. Rothwell. Talent Management: Aligning Your Organisation with the Best Practices in Strategic and Tactical Talent Management. Training \& Development, vol.39, no. 1, pp.12-14, 2012.

16. V. D. Kummerfeldt. Human Resource Management Strategies for Volunteers: A Study of Job Satisfaction, Performance, and Retention in a Nonprofit Organization (Doctoral dissertation, Capella University), 2011.

17. C. Tansley. What Do We Mean by the Term "Talent" in Talent Management? Industrial and Commercial Training, vol.43, no.5, pp.266-274, 2011.

18. S. Florin," Managing Talent in the Modern Business World". International Journal of Multidisciplinary and Current Research, pp.2321-3124, 2015. 
19. P. Iles, D, Preece, and X. Chuai,. Talent Management as a Management Fashion in HRD: Towards a Research Agenda. Human Resource Development International, vol.13, pp.125-145, 2010.

20. A. De Vos and N. Soens, "The Power of Career Counseling for Enhanced Talent and Knowledge Management', in Vaiman, V. and Vance, C.M. (Eds), Smart Talent Management - Building Knowledge Assets for Competitive Advantage, Edward Elgar Publishing, Aldershot, pp. 119-38, 2008.

21. S. Nilsson, \& P. E. Ellström. Employ Ability and Talent Management: Challenges for HRD Practices. European Journal of Training and Development, vol.36, no.1, pp. 26$45,2012$.

22. Lt. Gogate, S. Pandey, "Impact of Structured Induction on Mutually Beneficial Deployment and Talent Retention",
Indian Journal of Science and Technology, vol.8, no.10, pp. $17485,2015$.

23. C. A. Mohan, B. V. S. Prasad, \& P, Poonguzhali, Changing Role of HR Managers in Pharmaceutical Industry. International Journal of Pharmaceutical Sciences Review and Research, vol.30, no.2, pp.13: 83-87, 2015.

24. M. Beheshtifar, H. Y Nasab and M. N. Moghadam, Effective Talent Management: A Vital Strategy to Organizational Success. International Journal of Academic Research in Business and Social Sciences, vol.2, no.12, pp.227-234, 2012.

\section{Bentolhoda Abdollahbeigi}

hoda_beigi@yahoo.com

Farhang Salehi

salehi_farhang@yahoo.com

Dr. Sreenivasan Jayashree

jshree@mmu.edu.my

Multimedia University Jalan Multimedia, 63000 Cyberjaya, Selangor, Malaysia 